\title{
Profil nyeri di poliklinik saraf RSUP Prof. Dr. R. D. Kandou Manado periode 1 Januari 2014 - 31 Desember 2014
}

\author{
${ }^{1}$ Anisa F. Amalia \\ ${ }^{2}$ Theresia Runtuwene \\ ${ }^{2}$ Mieke A. H. N. Kembuan
}

\author{
${ }^{1}$ Kandidat Skripsi Fakultas Kedokteran Universitas Sam Ratulangi Manado \\ ${ }^{22}$ Bagian/SMF Neurologi Fakultas Kedokteran Universitas Sam Ratulangi Manado \\ Email: ica.amalia.27@gmail.com
}

\begin{abstract}
Pain is an unpleasant sensory and emotional experience associated with actual or potential tissue damage, or describe in terms of such damage. Pain may harm a patient's quality of life. Pain is an important co-morbidity of some diseases. Pain can be influenced by several factors such as age, gender, occupation, educational level, and individual life style. Some epidemiologic studies showed that there are variant factors that influence pain prevalence or incidence in several countries. This is a descriptive retrospective study using medical records of pain patient based on diagnose, age, gender, occupation, and educational level. The result showed that there were 1052 pain cases. Most cases was neurophatic pain $(51.3 \%)$ and nociceptive pain $(41.9 \%)$. Most of neurophatic pain was diabetic neuropathy $(72.2 \%)$ and nociceptive pain was low back pain $(52.2 \%)$. Pain incidence increased up to the 55 - 64 age group. Female suffered pain more frequent than male (58.7\%). Based on occupation, housewives reported pain more frequent (28.8\%). Most of pain patient graduated from high school degree (73.9\%).
\end{abstract}

Keywords: pain

\begin{abstract}
Abstrak: Nyeri adalah pengalaman sensorik dan emosional yang tidak menyenangkan akibat kerusakan jaringan, baik aktual maupun potensial, atau yang digambarkan dalam bentuk kerusakan tersebut. Perasaan nyeri dapat sangat mengganggu kualitas hidup seseorang. Nyeri merupakan faktor komorbiditas penting berbagai penyakit. Nyeri dapat dipengaruhi oleh usia, jenis kelamin, pekerjaan, tingkat pendidikan, budaya, serta kebiasaan atau gaya hidup individu. Beberapa studi epidemiologi menunjukan bahwa terdapat variasi faktor-faktor yang memengaruhi nyeri dalam prevalensi atau insidensi nyeri di beberapa negara. Jenis penelitian ini ialah deskriptif retrospektif, dengan menggunakan data rekam medik pasien nyeri berdasarkan diagnosis, usia, jenis kelamin, pekerjaan, dan tingkat pendidikan. Hasil penelitian memperlihatkan jumlah kasus nyeri sebanyak 1052 kasus. Kasus nyeri terbanyak adalah nyeri neuropatik (51.3\%) dan nyeri nosiseptif (41.9\%). Sebagian besar kasus nyeri neuropatik adalah neuropati diabetik $(72.2 \%)$ dan sebagian besar kasus nyeri nosiseptif adalah nyeri punggung bawah (52.2\%). Insidensi nyeri didapatkan terbanyak pada rentang usia 55-64 tahun (35.6\%). Perempuan lebih banyak menderita nyeri dibandingkan laki-laki (58.7\%). Profesi pada penderita nyeri terbanyak adalah ibu rumah tangga (28.8\%). Tingkat pendidikan nyeri yang terbanyak adalah tingkat pendidikan SMA $(73.9 \%)$.
\end{abstract}

Kata kunci: nyeri

Nyeri adalah pengalaman sensorik dan emosional yang tidak menyenangkan akibat kerusakan jaringan, baik aktual maupun potensial, atau yang digambarkan dalam 
bentuk kerusakan tersebut. ${ }^{1}$ Nyeri menjadi alasan tersering mengapa pasien datang untuk mencari pertolongan medis. Perasaan nyeri dapat sangat mengganggu kualitas hidup seseorang, namun sebenarnya nyeri adalah peringatan bahwa terdapat kerusakan jaringan sehingga dapat memberikan peringatan untuk menghindarkan diri dari bahaya yang dapat mengancam nyawa. ${ }^{2}$

Nyeri merupakan faktor komorbiditas penting pada banyak penyakit. Nyeri dapat dipengaruhi oleh usia, jenis kelamin, pekerjaan, tingkat pendidikan, budaya, serta kebiasaan atau gaya hidup individu. Beberapa studi epidemiologi menunjukan bahwa terdapat variasi faktor-faktor yang memengaruhi nyeri dalam prevalensi atau insidensi nyeri di beberapa negara.

Studi epidemiologi di Inggris menunjukan prevalensi nyeri lebih sering terjadi pada wanita dan meningkat pada usia lanjut. Nyeri juga didapatkan meningkat pada kelompok status sosioekonomi yang rendah terutama nyeri kepala. ${ }^{3}$ Penelitian di Jakarta Selatan pada tahun 2006 mengenai prevalensi nyeri muskuloskeletal pada lansia menunjukkan prevalensi nyeri pada lansia sebanyak $80 \%$, sebagian besar adalah wanita, dan terbanyak di lutut. Berbeda dengan studi terdahulu yang menyatakan bahwa nyeri pada muskuloskeletal terbanyak adalah nyeri punggung bawah. ${ }^{4}$ Kelompok studi nyeri Perhimpunan Dokter Spesialis Saraf Indonesia (Pokdi Nyeri Perdossi) pada bulan Mei 2002 di 14 rumah sakit pendidikan di seluruh Indonesia melaporkan bahwa jumlah penderita lakilaki sebanyak 2200 dan perempuan 2256. Kasus terbanyak adalah nyeri kepala diikuti oleh nyeri punggung bawah, nyeri neuropatik, dan nyeri lainnya seperti nyeri bahu, sendi, miofasial, dan sebagainya. ${ }^{5}$

Berdasarkan mekanisme, nyeri dibedakan menjadi nyeri nosiseptif, nyeri neuropatik, dan nyeri campuran. Nyeri nosiseptif adalah nyeri yang timbul karena adanya kerusakan pada jaringan non-saraf (somatik atau visera) baik aktual maupun berpotensi terjadi dan disebabkan oleh adanya aktivasi pada nosiseptor. Nyeri nosiseptif dapat ditemukan di klinis pada osteoartritis, reumatoid artritis, gout artritis, artalgia, nyeri punggung bawah, dan myalgia. ${ }^{6}$

Nyeri neuropatik didefinisikan sebagai nyeri yang disebabkan oleh adanya lesi atau disfungsi primer pada sistem saraf. ${ }^{1}$ Mekanisme nyeri neuropatik secara garis besar dibagi menjadi mekanisme sentral dan perifer. Nyeri sentral dapat ditemukan pada pasien stroke atau pasca trauma spinal. ${ }^{7}$ Nyeri neuropatik perifer terjadi akibat adanya kerusakan pada saraf perifer. Contoh nyeri neuropatik perifer adalah neuralgia postherpetik, neuropati diabetik, neuralgia trigeminal, kausalgia, phantom limb pain, carpal tunnel syndrome, dan radikulopati. ${ }^{8,9}$

Nyeri yang melibatkan kedua mekanisme gabungan nosiseptif dan neuropatik digolongkan dalam nyeri campuran atau mixed pain. Nyeri kanker, cervical root syndrome, nyeri punggung bawah dengan radikulopati, dan carpal tunnel syndrome dengan nyeri campuran adalah contoh nyeri campuran. ${ }^{10}$

Berdasarkan uraian diatas, maka penulis tertarik untuk melakukan penelitian tentang gambaran distribusi nyeri di poliklinik saraf RSUP Prof. Dr. R. D. Kandou Manado periode 1 Januari 2014 31 Desember 2014 dan gambaran distribusi nyeri berdasarkan rentang usia, jenis kelamin, pekerjaan, dan tingkat pendidikan.

\section{METODE PENELITIAN}

Jenis penelitian ini ialah deskriptif retrospektif dengan menggunakan data dari catatan rekam medik pasien di Instalasi Rekam Medik dan buku register di Poliklinik Saraf RSUP. Prof. Dr. R. D. Kandou Manado. Populasi dari penelitian ini adalah semua pasien yang datang berkunjung di Poliklinik Saraf RSUP. Prof. Dr. R. D. Kandou Manado. Sampel adalah semua pasien nyeri yang digolongkan berdasarkan diagnosis dari nyeri nosiseptif, nyeri neuropatik, dan nyeri campuran. Dari catatan medik pasien yang dicatat meliputi diagnosis, umur, jenis kelamin, pekerjaan, dan tingkat pendidikan. Data yang sudah 
terkumpul diolah menggunakan Microsoft Excel dan disusun menggunakan komputer, kemudian dianalisis dan disajikan dalam bentuk Tabel.

\section{HASIL PENELITIAN}

Berdasarkan penelitian yang dilakukan di Poliklinik Saraf RSUP. Prof. Dr. R. D. Kandou Manado tahun 2014 didapatkan jumlah kasus nyeri sebanyak 1052 kasus yang memenuhi kriteria penelitian. Jumlah kasus nyeri terbanyak adalah nyeri neuropatik yaitu sebanyak 540 kasus $(51.3 \%)$, diikuti oleh nyeri nosiseptif 441 kasus $(41.9 \%)$ dan nyeri campuran 71 kasus $(6.7 \%)$.

Tabel 1. Distribusi Kejadian Nyeri

\begin{tabular}{lcc}
\hline \multirow{2}{*}{ Diagnosis } & \multicolumn{2}{c}{ Jumlah } \\
& $\mathrm{N}$ & $\%$ \\
\hline Nyeri Nosiseptif & 441 & 41.9 \\
Nyeri Neuropatik & 540 & 51.3 \\
Nyeri Campuran & 71 & 6.7 \\
Total & 1052 & 100.0 \\
\hline
\end{tabular}

Jumlah kasus nyeri nosiseptif pada Tabel 2 terbanyak adalah nyeri punggung bawah sebanyak 230 kasus (52.2\%), diikuti oleh osteoartritis 80 kasus (18.1\%), artralgia dan frozen shoulder 57 kasus $(12.9 \%)$, myalgia 38 kasus $(8.6 \%)$, gout artritis 35 kasus (7.9\%), dan artritis reumatoid 1 kasus $(0.2 \%)$.

Tabel 2. Distribusi Nyeri Nosiseptif

\begin{tabular}{lcc}
\hline \multirow{2}{*}{ Diagnosis } & \multicolumn{2}{c}{ Jumlah } \\
& $\mathrm{N}$ & $\%$ \\
\hline Osteoartritis & 80 & 18.1 \\
Artritis Reumatoid & 1 & 0.2 \\
Gout Artritis & 35 & 7.9 \\
Artalgia / Frozen Shoulder & 57 & 12.9 \\
Nyeri Punggung Bawah & 230 & 52.2 \\
Myalgia & 38 & 8.6 \\
Total & 441 & 100.0 \\
\hline
\end{tabular}

Tabel 3 menunjukkan jumlah kasus terbanyak pada neuropati diabetik yaitu sebanyak 390 kasus (72.2\%). Jumlah kasus untuk radikulopati sebanyak 68 kasus (12.6\%), neuralgia trigeminal 53 kasus (9.8\%), carpal tunnel syndrome 15 kasus
(2.8\%), neuralgia post herpetik 8 kasus $(1.5 \%)$, central post stroke pain (CPSP) atau nyeri sentral pasca stroke sebanyak 5 kasus $(0.9 \%)$, dan nyeri pasca trauma medula spinalis sebanyak 1 kasus $(0.2 \%)$.

Tabel 3. Distribusi Nyeri Neuropatik

\begin{tabular}{lcc}
\hline \multirow{2}{*}{ Diagnosis } & \multicolumn{2}{c}{ Jumlah } \\
& $\mathrm{N}$ & $\%$ \\
\hline Neuralgia post herpetik & 8 & 1.5 \\
Neuropati diabetik & 390 & 72.2 \\
Neuralgia trigeminal & 53 & 9.8 \\
Kausalgia & 0 & 0.0 \\
Phantom limb pain & 0 & 0.0 \\
Carpal tunnel syndrome & 15 & 2.8 \\
Radikulopati & 68 & 12.6 \\
CPSP & 5 & 0.9 \\
Nyeri pasca trauma & & \\
medula spinalis & 1 & 0.2 \\
Total & 540 & 100.0 \\
\hline
\end{tabular}

Berdasarkan hasil penelitian distribusi nyeri campuran pada Tabel 4, diperoleh jumlah kasus cervical root syndrome sebanyak 42 kasus (59.2\%) dan nyeri punggung bawah dengan radikulopati sebanyak 29 kasus (40.8\%).

Tabel 4. Distribusi Nyeri Campuran

\begin{tabular}{lcc}
\hline \multirow{2}{*}{ Diagnosis } & \multicolumn{2}{c}{ Jumlah } \\
& $\mathrm{N}$ & $\%$ \\
\hline Nyeri kanker & 0 & 0.0 \\
Cervical root syndrome & 42 & 59.2 \\
LBP dengan Radikulopati & 29 & 40.8 \\
Carpal tunnel syndrome & 0 & 0.0 \\
Total & 71 & 100.0 \\
\hline
\end{tabular}

Berdasarkan hasil penelitian pada Tabel 5 diketahui bahwa distribusi nyeri terbanyak terdapat pada kelompok usia 5564 tahun yaitu berjumlah 374 pasien (35.6\%), diikuti oleh kelompok usia 65-74 tahun (22.8\%), kelompok usia 45-54 tahun (21.2\%), kelompok usia 35-44 tahun (9.4\%), kelompok usia lebih dari 75 tahun (6.8\%), kelompok usia 25-34 tahun (2.9\%), dan yang terendah terdapat pada kelompok usia 15-24 tahun (1.3\%).

Tabel 6 menunjukkan distribusi nyeri terbanyak ialah pada perempuan sebanyak 618 pasien $(58.7 \%)$ dan laki-laki sebanyak 
434 pasien $(41.3 \%)$

Tabel 5. Distribusi Nyeri Berdasarkan Usia

\begin{tabular}{ccc}
\hline \multirow{2}{*}{ Usia } & \multicolumn{2}{c}{ Jumlah } \\
& $\mathrm{N}$ & $\%$ \\
\hline $15-24$ tahun & 14 & 1.3 \\
$25-34$ tahun & 30 & 2.9 \\
$35-44$ tahun & 99 & 9.4 \\
$45-54$ tahun & 223 & 21.2 \\
$55-64$ tahun & 374 & 35.6 \\
$65-74$ tahun & 240 & 22.8 \\
$>75$ tahun & 72 & 6.8 \\
Total & 1052 & 100.0 \\
\hline
\end{tabular}

Tabel 6. Distribusi Nyeri Berdasarkan Jenis Kelamin

\begin{tabular}{ccc}
\hline \multirow{2}{*}{ Jenis Kelamin } & \multicolumn{2}{c}{ Jumlah } \\
& $\mathrm{N}$ & $\%$ \\
\hline Laki - Laki & 434 & 41.3 \\
Perempuan & 618 & 58.7 \\
Total & 1052 & 100.0 \\
\hline
\end{tabular}

Pada Tabel 7 didapatkan pekerjaan dengan angka kejadian nyeri tertinggi ialah ibu rumah tangga (28.8\%), diikuti oleh pegawai negeri sipil (PNS) (22.2\%), pensiunan $(16.2 \%)$, pegawai swasta $(8.5 \%)$, wiraswasta $(5.8 \%)$, lain-lain $(5.6 \%)$, petani $(4 \%)$, dosen atau guru (2\%), buruh (2\%), supir (1.5\%), pelajar atau mahasiswa (1.4\%), tidak bekerja (1\%), TNI/polri $(0.6 \%)$ dan nelayan $(0.6 \%)$.

Tabel 7. Distribusi Nyeri Berdasarkan Pekerjaan

\begin{tabular}{lcc}
\hline \multirow{2}{*}{ Pekerjaan } & \multicolumn{2}{c}{ Jumlah } \\
& $\mathrm{N}$ & $\%$ \\
\hline Buruh & 21 & 2.0 \\
Dosen / Guru & 21 & 2.0 \\
Ibu Rumah Tangga & 303 & 28.8 \\
Nelayan & 6 & 0.6 \\
Pegawai Swasta & 89 & 8.5 \\
Pelajar / Mahasiswa & 14 & 1.3 \\
PNS & 234 & 22.2 \\
Pensiunan & 170 & 16.2 \\
Petani & 42 & 4.0 \\
Supir & 16 & 1.5 \\
TNI/polri & 6 & 0.6 \\
Wiraswasta & 61 & 5.8 \\
Tidak bekerja & 10 & 1.0 \\
Lain-lain & 59 & 5.6 \\
Total & 1052 & 100.0 \\
\hline
\end{tabular}

Tabel 8 menunjukkan distribusi nyeri berdasarkan tingkat pendidikan terbanyak ialah SMA berjumlah 777 pasien (73.9\%), kemudian diikuti oleh tingkat pendidikan perguruan tinggi 104 pasien (9.9\%), SMP 99 pasien $(9.4 \%)$, SD 66 pasien $(6.3 \%)$, dan tidak tamat SD 6 pasien $(0.6 \%)$.

Tabel 8. Distribusi Nyeri Berdasarkan Tingkat Pendidikan

\begin{tabular}{lcc}
\hline \multirow{2}{*}{ Pendidikan } & \multicolumn{2}{c}{ Jumlah } \\
& $\mathrm{N}$ & $\%$ \\
\hline Tidak tamat SD & 6 & 0.6 \\
SD & 66 & 6.3 \\
SMP & 99 & 9.4 \\
SMA & 777 & 73.9 \\
Perguruan Tinggi & 104 & 9.9 \\
Total & 1052 & 100.0 \\
\hline
\end{tabular}

\section{BAHASAN}

Berdasarkan hasil penelitian yang dilakukan di poliklinik saraf RSUP Prof. Dr. R. D. Kandou Manado pada periode 1 Januari 2014-31 Desember 2014 didapatkan jumlah kasus nyeri yang sesuai dengan kriteria inklusi berjumlah 1052 kasus. Dari jumlah 1052 kasus nyeri tersebut, didapatkan jumlah nyeri terbanyak ialah nyeri neuropatik sebanyak 540 kasus $(51.3 \%)$ diikuti oleh nyeri nosiseptif sebanyak 441 kasus (41.9\%). Jumlah kasus terbanyak pada nyeri neuropatik adalah neuropati diabetik sebanyak 390 pasien (72.2\%). Menurut penelitian Bennet yang dikutip dari The journal of the American Osteopathic Association menyatakan kasus nyeri neuropatik terbanyak di Amerika Serikat adalah neuropati diabetik yang berjumlah 600 kasus per 100.000 dari total 1680 juta kasus nyeri neuropatik. ${ }^{11}$ Neuropati diabetik merupakan penyulit tersering pada diabetes melitus terutama setelah hiperglikemia kronik. Banyak penelitian yang menyatakan bahwa terdapat keterkaitan erat antara gangguan toleransi glukosa dan neuropati. ${ }^{12}$ Berdasarkan data dari RISKESDAS pada tahun 2013, Sulawesi Utara menempati urutan kedua terbanyak pada kasus diabetes melitus di Indonesia. ${ }^{13}$ Tingginya angka kejadian diabetes melitus di Sulawesi Utara, 
kurangnya pengendalian glukosa darah pada penderita diabetes melitus, dan pola hidup masyarakat yang berisiko menjadi faktor yang berperan dalam tingginya angka kejadian neuropati diabetik.

Pada nyeri nosiseptif, kasus nyeri terbanyak terdapat pada nyeri punggung bawah atau low back pain yaitu sebanyak 230 pasien $(52.2 \%)$. Hasil penelitian yang sama terdapat pada penelitian yang dilakukan oleh Schopflocher $\mathrm{dkk}^{14} \mathrm{di}$ Canada pada tahun 2011 yang menyatakan nyeri kronik yang paling banyak ditemukan adalah nyeri punggung bawah yaitu sebesar $35.5 \%$. Insidensi nyeri punggung bawah berkaitan erat dengan usia, yaitu dimulai pada usia dekade ke dua dan insidensi tinggi dijumpai pada dekade ke lima. Selain itu, faktor lain yang berpengaruh dalam insidensi nyeri punggung bawah adalah obesitas, kurang aktivitas fisik, dan faktor biomekanis dalam pekerjaan. ${ }^{15}$ Faktorfaktor tersebut merupakan masalah gaya hidup yang sering ditemukan pada masyarakat perkotaan yang mungkin menyebabkan tingginya insidensi nyeri punggung bawah di wilayah kota Manado.

Hasil penelitian distribusi nyeri berdasarkan usia yang dilakukan menunjukkan bahwa terdapat peningkatan insidensi nyeri seiring dengan bertambahnya usia dan mencapai puncak insidensi nyeri tertinggi yaitu pada kelompok usia $55-64$ tahun yaitu sebanyak 374 pasien (35.6\%), kemudian insidensi menurun pada kelompok usia diatas 65 tahun. Menurut National Center for Health Statistics tahun 2006 di Amerika Serikat, insidensi nyeri tertinggi adalah pada kelompok usia 45 - 64 tahun yaitu sebesar 30\%, dan kelompok usia di atas 65 tahun merupakan kelompok usia yang paling sedikit melaporkan nyeri yaitu sebesar 21\%. ${ }^{16}$ Moulin dkk $^{17}$ dalam penelitiannya mengatakan penderita nyeri di Canada meningkat pada kelompok usia diatas 55 tahun yaitu sebesar 39\%. Insidensi nyeri didapatkan meningkat pada usia lanjut. Secara keseluruhan, pengaruh usia terhadap nyeri bersifat kompleks yaitu adanya peningkatan risiko berbagai penyakit pada usia lanjut dan bergantung pada perubahan patofisiologi, farmakokinetik, dan farmakodinamik yang terjadi pada usia lanjut. ${ }^{18}$

Sebagian besar pasien nyeri yang didapatkan pada hasil penelitian adalah perempuan yaitu berjumlah 618 pasien atau sebesar $58.7 \%$, sedangkan jumlah pasien nyeri pada laki-laki berjumlah 434 pasien atau sebesar $41.3 \%$. Menurut data dari penelitian multisenter yang dilakukan oleh kelompok studi nyeri Perhimpunan Dokter Spesialis Saraf Indonesia (Pokdi Nyeri Perdossi) pada bulan Mei 2002, didapatkan jumlah pasien nyeri pada perempuan adalah lebih banyak bila dibandingkan dengan laki-laki yaitu berjumlah 2256 pasien, sedangkan laki-laki berjumlah 2200 pasien. ${ }^{10}$ Penelitian oleh Moulin $\mathrm{dkk}^{17} \mathrm{di}$ Canada, mengatakan hal yang sama yaitu prevalensi nyeri pada perempuan adalah 4\% lebih besar dibandingkan laki-laki. Hal tersebut dapat dikatakan insidensi nyeri pada perempuan memiliki nilai yang konstan yaitu lebih tinggi dibandingkan jumlah pasien nyeri pada laki-laki. Mekanisme yang terkait adalah adanya faktor biologis yaitu hormon dalam modulasi nyeri dan adanya faktor psikososial seperti peran jenis kelamin. ${ }^{18}$ Namun saat ini para ahli masih memperdebatkan apakah perbedaan jenis kelamin ini didasari oleh mekanisme biologis nyeri atau terdapat kontribusi dari faktor psikologis dan faktor sosial. ${ }^{19}$

Pada hasil penelitian didapatkan jumlah kasus nyeri terbanyak adalah pasien dengan pekerjaan ibu rumah tangga yaitu sebesar 303 pasien (28.8\%). Pekerjaan memiliki banyak faktor yang dapat dikaitkan dengan insidensi nyeri, terutama nyeri muskuloskeletal. Yilmaz dan Dedeli, ${ }^{15}$ dalam penelitiannya mengatakan pekerjaan ibu rumah tangga sering dikaitkan insidensinya dengan kejadian nyeri punggung bawah. Faktor biomekanis dan faktor psikososial pada tempat kerja dinilai merupakan faktor dalam pekerjaan yang berperan dalam insidensi nyeri. ${ }^{15,20}$

Tingkat pendidikan dinilai berhubungan dengan tingkat kognitif 
seseorang yang dapat berpengaruh dalam persepsi nyeri yang dirasakan dan adanya perbedaan dalam pengetahuan dan pemahaman berbagai risiko dalam kesehatan. ${ }^{21}$ Berdasarkan hasil penelitian didapatkan sebagian besar penderita nyeri adalah berpendidikan SMA yaitu sebesar $73.9 \%$. Atlas $\mathrm{SJ}^{21}$ dalam penelitiannya mengatakan adanya perbedaan insidensi nyeri kronik pada pasien dengan pendidikan setara perguruan tinggi yaitu sebesar $26 \%$ dan $55 \%$ pada pasien yang tidak lulus pendidikan SMA. Tingkat pendidikan juga berhubungan dengan status sosioekonomi seseorang. Banyak studi mengatakan status sosioekonomi yang rendah yaitu tingkat pendidikan yang rendah, pendapatan rendah, atau orang yang tidak memiliki pekerjaan berhubungan dengan peningkatan insidensi nyeri. ${ }^{19}$ Hasil penelitian yang berbeda didapatkan oleh Nakamura $\mathrm{M}, \mathrm{dkk}^{22}$ pada penelitian insidensi nyeri kronik di Jepang yaitu pasien nyeri kronik lebih banyak pada pasien dengan pendidikan teknik atau setara perguruan tinggi sebesar $12.4 \%$ sedangkan pendidikan SMA atau lebih rendah berjumlah 9.8\%. Dalam penelitian tersebut didapatkan insidensi nyeri kronik berhubungan dengan status sosioekonomi yang tinggi yang termasuk diantaranya yaitu pekerjaan sebagai professional dan tingkat pendidikan tinggi. Secara keseluruhan, tingkat pendidikan tidak hanya berperan dalam pengaruh kognitif yang berperan dalam insidensi nyeri, tetapi juga berperan dengan adanya faktor pekerjaan dalam menilai status sosiokenomi yang menjadi faktor risiko dalam insidensi nyeri.

\section{SIMPULAN}

Berdasarkan hasil penelitian dan bahasan dapat disimpulkan bahwa kasus nyeri terbanyak ialah nyeri neuropatik yang sebagian besar ialah neuropati diabetik. Sebagian besar kasus nyeri nosiseptif ialah nyeri punggung bawah.

Mayoritas kasus nyeri ialah kelompok usia 55-64 tahun, perempuan, pekerjaan sebagai ibu rumah tangga, dan pendidikan terakhir ialah tingkat pendidikan SMA.

\section{SARAN}

Diharapkan adanya penelitian lanjut mengenai penyakit dengan nyeri yang sering ditemukan dan variabel yang lebih luas. Diperlukan adanya peningkatan upaya pencegahan dan terapi yang efektif terhadap nyeri oleh pasien dan juga tenaga kesehatan yang dapat menjadi faktor penting dalam mencegah atau mengurangi insidensi nyeri di masyarakat.

\section{DAFTAR PUSTAKA}

1. International Association for the Study of Pain. IASP taxonomy. 2012 Mei 22 [cited 2016 Aug 31]. Available from: http://www.iasp-pain.org/Taxonomy

2. Satyanegara. Ilmu bedah saraf. Edisi ke-5. Jakarta: Gramedia; 2014. h. 301-9.

3. King S, Chamber CT, Huguet A, MacNevin RC, McGrath PJ, Parker, et al. The epidemiology of chronic pain in children and adolescents revisited: A systematic review. J.pain. 2011;152:2729-38.

4. Rachmawati MR, Samara D, Tjhin P, Wartono M. Nyeri muskuloskeletal dan hubungannya dengan kemampuan fungsional fisik pada lanjut usia. Universa Medicina. 2006;25(4):179-83.

5. Meliala L. Nyeri: Keluhan yang terabaikan konsep dahulu, sekarang dan yang akan datang. 2004 Des 6 [cited 2016 Agustus 25]. Available from: https://www.scribd.com/doc/2097655 90

6. Meliala L, Alexander J, Hartanto YB. New insight in nociceptive pain management: focus on safety and efficacy of celecoxib. In: Gofir A, Karema W, Runtuwene T, Kembuan M, Khosama H, Mawuntu A, editors. Konas Perdossi ke-7; 2011 July 2123; Manado. Pustaka cendikia press; 2011.

7. Soeroso J, Kertia N, Susanti VY. Nyeri neuropatik. In: Setiati S, Alwi I, Sudoyo AW, Simadibrata M, Setiyohadi B, Syam AF, editors. Buku ajar ilmu penyakit dalam. Edisi ke-6. Jakarta: InternaPublishing; 2014. h. 3541-8. 
8. Meliala L, Alexander J, Hartanto YB. Update in acute neuropathic pain. In: Gofir A, Karema W, Runtuwene T, Kembuan M, Khosama H, Mawuntu A, editors. Konas Perdossi ke-7; 2011 July 21-23; Manado. Pustaka cendikia press; 2011.

9. International Neuromodulation Society. Painful peripheral Neuropathy. 2012 Oct 28 [cited 2012 Sep 3]. Available from:

http://www.neuromodulation.com/fac t_sheet_painful_peripheral_neuropath $\mathrm{y}$

10. Wibowo BS. Dampak klinis dan pilihan terapi pada mixed pain. In: Leksmono P, Islam MS, Haryono Y, editors. Kumpulan makalah pertemuan ilmiah nasional II Perdossi: Nyeri kepala, nyeri \& vertigo. Airlangga university press. 2006. h. 106-7.

11. The Journal of the American Osteopathic Association. Managing neuropathic pain. 2007 Nov [cited 2016 Nov 12]. Available from: http://jaoa.org/article.aspx ?articleid=2 093586

12. Hartwig MS, Wilson LM. Nyeri. In: Price SA, Wilson LM, editors. Patofisiologi: konsep klinis prosesproses penyakit. Edisi ke-6. Jakarta: EGC; 2005. h. 1063-89.

13. Pusat data dan informasi kementrian kesehatan RI. Situasi dan analisis diabetes. 2014 Nov [cited 2016 Nov 19]. Available from: http://www.depkes.go.id/resources/do wnload/pusdatin/infodatin/infodatindiabetes.pdf
14. Schopflocher D, Taenzer P, Jovey R. The prevalence of chronic pain in Canada. Pain Res Manag. 2011; 16(6):445-50.

15. Yilmaz E, Dedeli O. Effect of physical and psychosocial factors on occupational low back pain. Health Science Journal. 2012;6:599-604.

16. National center for health statistics. Health, United States, 2006. 2006. [cited 2016 Nov 13]. Available from: www.cdc.gov/nchs/data/hus/hus06.pd $\mathrm{f}$

17. Moulin DE, Clark AJ, Speechley M, Morley PK. Chronic pain in Canadaprevalence, treatment, impact and the role of opioid analgesia. Pain Res Manag. 2002; 7:179-84.

18. Belfer I. Nature and Nurtue of human pain. Hindawi Publishing Corporation Scientifica. 2013;2013:1-2.

19. Nicholas H, Kamper SJ, Maher CG. The epidemiology and economic consequences of pain. Pub Med. 2015;90:139-45.

20. Kopec AJ, Sayre EC. Work-related psychosocial factors and chronic pain: prospective cohort study in Canadian workers. J Occup Environ Med. 2004;46:1263-71.

21. Atlas SJ. Education and the prevalence of pain. NBER. 2010;1.

22. Nakamura M, Nishiwaki Y, Ushida T, Toyama Y. Prevalence and characteristics of chronic musculoskeletal pain in Japan: A second survey of people with or without chronic pain. Journal of Orthopaedic Science. 2014; 19:33950. 